\title{
Empire-Building, Imperial Policies, and Famine in Occupied Territories and Colonies ${ }^{1}$
}

\author{
Bohdan Klid \\ University of Alberta
}

\begin{abstract}
The introductory article to the special issue "Empire, Colonialism, and Famine in the Nineteenth and Twentieth Centuries" begins by pointing to some recent literature on famine theory, where stress has been made on responses of authorities to famine and on the political nature of modern famines. Literature on the connection between imperial policies, colonial rule, and famine is also briefly discussed. The Soviet Union is treated as an empire in the essay, and some of the literature on this question is also surveyed. The article then offers summaries of and highlights from essays in this volume that resulted from papers presented at two conferences on the theme "Empires and Famines in Comparative Historical Perspective," held in 2016 in Toronto and in 2017 in Kyiv. These include papers on famine and food policies during World War II in occupied Ukraine and Moldova. Essays on famines in Soviet Ukraine, British-ruled Ireland, and British-ruled Bengal, India, are summarized as well as an essay on Raphaël Lemkin's views on genocide and famine and an essay that looked at minorities in Mao's China during the 1958-62 famine. The essay concludes with the observation that the investigation of imperial policies, colonial rule, and famine should be pursued further, especially in the case of the Soviet Union where this line of research is just beginning.
\end{abstract}

Keywords: Soviet Union, famine, Ukraine, empire, imperialism, colonialism, genocide, India, Ireland, China.

D

roughts and other natural disasters have led and can lead to serious food shortages. However, as Amartya Sen stressed in his groundbreaking study Poverty and Famines, declines in food availability need not result in starvation. When mass deaths occur, it nearly always involves decisions about distribution of food supplies and whether food is made accessible to those who need it. $^{2}$

1 This paper has incorporated parts of the concept statement prepared for the Kyiv 2017 conference "Imperii, kolonii ta holod v istoryko-porivnial'nii perspektyvi" ("Empire, Colonialism and Famine in Comparative Historical Perspective") by the late Mark von Hagen and Liudmyla Hrynevych, who also initiated the idea of holding the conference.

2 In Poverty and Famines, Sen elaborates on the "entitlement approach" to understanding why famines occur. This work ushered in a new famine literature that 
Sen in a later study argued that famines have not occurred in independent, democratic countries, suggesting a link between the existence of political liberties and civil rights and the absence of famine. Conversely, famines and mass starvation have occurred in countries where citizens lacked these rights (see Development As Freedom 151-52, 178-88). ${ }^{3}$ It follows, therefore, that famines occurring in states where basic human rights are suppressed or absent can be seen as drawn-out forms of political violence that deprive people of the fundamental human right to life. ${ }^{4}$

Sen also pointed to a link between famine and colonial rule. Commenting on the Irish famines of the 1840s, he highlighted the "cultural alienation" in British-ruled Ireland, even though it was a part of the UK and had not been governed as a colony since 1800. Sen suggested that the political commitment to prevent starvation in England did not apply to Ireland. In the case of the 1943 Bengal famine in British-ruled India, which Sen himself survived, British convictions of cultural superiority dovetailed with an asymmetrical political power relationship (Development As Freedom 17075).

In his path-breaking study, Mike Davis elaborates on the "political ecology of famine," making connections between British imperial ruleduring which capitalist development was transforming the economies of its colonial realms - and the deaths of millions of non-European peasants from hunger in the process of incorporation into the British and world economy. Building on insights from Karl Polanyi's The Great Transformation, Davis addresses famines in India, China, and Africa, but also sees early parallels in the Irish famine of the 1840s, placing it in the context of Thomas Malthus's ideas, which were exploited to justify constraints to famine relief in India as well $(9-10,15-16,32,46,306)$. The economist Stephen Devereux attributes some famines in the first part of the twentieth century to "synergies between drought and British/French colonial policies in West Africa, and German suppression of local uprisings in Tanzania" (Famine in the Twentieth Century 23). Alex de Waal, in his examination of the link between European colonialism and famines, uses the label "conquest famines," relying in part on Davis's study (53; see also 54, 67-73). Cormac Ó Gráda cautions, however, against an automatic linkage of colonialism and famine. In his view, the

\footnotetext{
has stressed the political nature of modern-era famines. For an overview of this literature, see Devereux, "Introduction"; and Edkins. In a recent study Alex de Waal concludes that modern famines are linked to political decisions or political failings.

${ }^{3}$ For a discussion of Sen's assertion that famines do not take place in democratic countries, see de Waal's chapter "Politics, War, Genocide," esp. pp. 94-99, in his Mass Starvation.

4 The topics of right to food as a basic human right, the denial of food to people by states, and state policies that cause hunger, are discussed in Howard-Hassmann.
} 
famines in nineteenth century British-ruled Ireland and India were attributable more to "the failure of the authorities of the day" than to colonial rule; he asserts that colonial authorities helped keep India free of famine in the early twentieth century up to the Bengal famine of 1943-44 (Ó Gráda 1920).

Recent scholarship on famines has thus focused attention not only on the policies and actions of governments that lead to famines, but also on their responses or failures to respond adequately to famine conditions, including in overseas colonies or peripheral regions (internal colonies) of empires. Some governments have not only exhibited little will to prevent mass starvation but have sought to achieve political goals by manipulating food production and distribution of food supplies, sometimes as a weapon or means of controlling and/or exterminating social classes and disloyal groups.

Imperial famines include instances where imperial rule or colonial governance, featuring the vertical hierarchy of metropolis and colony, leads to the sacrifice of lives at the peripheries for the supposed greater good of the empire or to support an imperial or empire-building project. Such cases are most evident during times of war in the policies and treatment of peoples under military occupation. However, famines have also occurred in times of peace, as in the cases of the Soviet Union and, later China, when the imperial centre used its coercive powers to overturn and remake the social and economic order. In the case of the Soviet Union, the famines of the early 1930s were most severe and deadly in peripheral regions, such as Ukraine and Kazakhstan, which were populated largely by national minorities.

To explore the role of empires and colonial rule in famines, the Holodomor Research and Education Consortium at the Canadian Institute of Ukrainian Studies, University of Alberta, organized two conferences on the theme "Empire, Colonialism and Famine in Comparative Historical Perspective," in 2016 in Toronto and in 2017 in Kyiv. Several papers focused on famine and food policies during World War II, as empire-building, colonization, and colonial rule have often been triggered by, accompanied, or followed wars of conquest, where food policies tied to war efforts have led to famine. Notably, scholarship on Nazi Germany and its hunger policies in Eastern Europe, including the siege of Leningrad and the starvation of Soviet prisoners of war, and the centrality of Ukraine in securing food and as a territory for colonization, have been studied in the context of imperialism and empire-building (see, for instance, Mazower; Snyder, Black Earth and Bloodlands). ${ }^{5}$ The connection between the quest for food security and

\footnotetext{
${ }^{5}$ Snyder emphasized the centrality of Ukraine and the enslavement of Ukrainians in Hitler's war plans in a speech before a gathering of Germany's Bundestag on 20 June
} 
empire-building during World War II was also the focus of the compelling study by Lizzie (Elizabeth) Collingham.

Three of the nine articles in the present special issue examine the food policies of Nazi Germany and its wartime ally Romania in occupied territories during World War II that are today part of Ukraine, Moldova, and Poland. While the outbreak of diseases, food shortages, and even famine often are triggered during wars, these two occupying powers through their policies deliberately caused starvation in their occupied territories. The primary victims were the minority populations of Roma and Jews, most of whom were massacred during the Holocaust. ${ }^{6}$

In his essay, Kiril Feferman gives an overview of Nazi food policies toward Jews on Polish and Soviet territories occupied by German forces. He asserts that the policies reflected the approaches of both the ideologists, who were apt to support the quick elimination of Jews, and those who advocated a more pragmatic approach. While during World War II it quickly became clear that the Nazis aimed to destroy the Jews in German-occupied territories, the pragmatists hoped to utilize them for forced labour to aid the German war effort, which meant that Jews needed to be fed enough to enable them to work. In occupied Poland, Jews were forced into ghettos where they were subject to the vagaries of policies between pragmatists and ideologists. Overall, the rations allotted Polish Jews were roughly equal to the starvationlevel rations allocated for POWs. The major goal of Jews then became to secure enough food to subsist. The search for food spawned widespread smuggling activities, carried out largely by children, which placed smugglers in danger of punishment, including execution. The struggle to obtain scarce food at elevated prices intensified competition, which led to denunciations to ghetto authorities or the Gestapo. (The topic of competition for survival is also discussed in Douglas Irvin-Erickson's essay in this volume.)

Paul Shapiro examines the treatment of Jews and Roma by Romanian authorities in occupied Bessarabia and Transnistria during World War II, and in particular, food policies toward these two minorities. Overall, there were similarities in food policies and in the treatment of Jews and Roma by Nazi German and Romanian authorities in occupied territories. It is widely known that agricultural products from German-occupied Ukraine were sent to Germany. Food products were also taken from territories occupied by Romanian troops such as Transnistria and sent to Romania, even while Romania, a subordinate ally of Nazi Germany, was sending its agricultural products to Nazi Germany. The treatment of Jews was especially inhumane,

2017 ("Germany's Historical Responsibility for Ukraine”). See also the chapter "Nazi Colonialism and Ukraine," in Lower (32-41).

${ }^{6}$ For a collection of essays on the Holocaust in Ukraine, see Brandon and Lower. 
brutal, and deadly, and derived from the aim of the Romanian government to cleanse its territory of Jews to achieve ethnic purity.

With the advance of Romanian forces into Bessarabia-the province annexed from Romania one year earlier by the Soviet Union-massacres, killings, and executions of Jews began, which were similar to acts committed by German killing units upon entering Soviet Ukrainian territories. Similarly, Jews and Roma were deported and forced into ghettos and camps administered by authorities of both wartime allies. Many Jews and Roma were doomed to die of starvation or diseases related to malnutrition because the authorities who controlled food supplies established a hierarchy of consumption, where the needs of the people in Romania and in the occupied lands took precedence over those of Jews and Roma.

Shapiro describes the treatment of Jews and Roma, who were rounded up into ghettos and then forced to march to camps. Jews already suffered from hunger and disease in the transit camps and ghettos before they were compelled to leave Bessarabia for Transnistria in forced marches. When reaching Transnistria, Jews and Roma also faced food shortages and hunger, as Romanian authorities exported food from Transnistria to Romania and also prioritized feeding the local population. The policies of occupation authorities to isolate the Jews and Roma, prevent their access to local markets, punish those who tried to go there, and prevent local inhabitants from bringing food to them intensified famine conditions. As the goal of Romanian authorities was to eliminate and reduce the presence of Jews and Roma, starvation of the two groups constituted acceptable state policy. The result was that most Jews and Roma under Romanian occupation died in Bessarabia and Transnistria. According to Shapiro, about 280,000 to 380,000 Jews died, as did nearly half of the 25,000 Roma deported by Romanian authorities from Romania proper and Bessarabia east to Transnistria and Ukraine.

Finally, the article, co-authored by Oleksandr Lysenko, Oleksandr Maievs'kyi, and Tetiana Zabolotna, ${ }^{7}$ demonstrates that the war created conditions for using famine as an instrument in achieving Nazi Germany's strategic goals in the eastern territories, one of which was to colonize Ukraine with German settlers. ${ }^{8}$ The population under occupation, largely Ukrainians, was to be subjected eventually to either resettlement or

\footnotetext{
7 This essay is a translation of a previously published article in Ukrainian, which is-an expanded and revised version of a presentation made at the 2017 Kyiv conference by Oleksandr Lysenko.

8 Timothy Snyder discusses Hitler's plans for colonizing Soviet Ukraine and food policies in occupied Reichskommissariat Ukraine in his monographs Black Earth and Bloodlands. Karel C. Berkhoff also devotes a chapter to the German policy of starvation in Ukraine's capital city (164-86).
} 
elimination. German government policy makers at the highest levels who authorized excessive food procurements, primarily for consumption in Germany and in German-occupied western Europe, knew that these policies would create famine conditions in the east that could lead to the deaths of millions. German military leaders who took part in organizing and directing food requisitioning and its export were also aware that these policies would cause hunger. Lysenko and others stress that Nazi food policies were aimed at attaining a reliable source of food supply for Germany and depopulating the eastern territories to allow for German colonization. These policies had a contradictory outcome, as Germany's need for food resources created shortages in the occupied territories, which sapped the morale and physical strength of its inhabitants, who were needed to produce the food. Eventually, Germany's food policies undermined its overall goals while causing enormous demographic losses among the inhabitants of the occupied territories.

Famine in German- and Romanian-occupied Ukraine during World War II was the direct result of the policies of occupation authorities. British India was not occupied by any of the Axis powers, but also was affected by famine. It was not, however, deliberately caused by British colonial authorities. Rather, Janam Mukherjee's essay argues that the outbreak of food shortages in Bengal in World War II stemmed basically from wartime conditions, while the failure to prevent mass starvation was linked more to policy failures in British-ruled India in 1943. When Great Britain declared war on Germany in September 1939, its colonial possessions were also drawn into the conflict. The British reverted to direct rule in India, as there was little or no support for the war effort among the Indian populace, and the main political force of the Indian subcontinent, the Indian National Congress, opposed it. The war, therefore, created conditions for the rise of authoritarian rule and provided justification for the confiscation and requisitioning of rice, which created chaos in the rice market and galloping inflation. Colonial officials failed to address adequately the critical food situation that ensued, which affected mostly the poor. Mukherjee notes that as the starvation of the poor was not a threat to the colonial regime or the war effort, it could be ignored by colonial officials.

In the second part of his paper Mukherjee looks at the political and economic effects of wartime developments in the colonial realm and the lingering effects of the famine in Bengal and, more widely, Indian society. Examining the political power relationships within the indigenous population, he notes that both Hindu and Muslim-led political forces referred to the famine and famine relief in their political power struggles. Although the Calcutta post-war riots of 1946 featured intense Hindu-Muslim violence that presaged events that would take place during the partition of the subcontinent, Mukherjee submits that these should not be seen as a 
direct consequence of the 1943 famine but viewed in a wider context of chronic, long-term, multi-generational poverty compounded by the war and the catastrophic famine.

State leaders, including of imperial states, have sought to minimize or deny culpability and suppress information related to famines they have induced, allowed to occur, or failed to alleviate. The decision of Winston Churchill's wartime British government not to send famine relief to India on "strategic grounds" helped seal the fates of 1.5 to 4 million people in Bengal-largely the poor-who died of famine and famine-related diseases in 1943. The authorities banned the first book to depict the tragedy, Hungry Bengal, in 1944, and five thousand copies were seized and destroyed (Collingham 141-54). An earlier determination to suppress information about a state-induced famine was Stalin's regime ban on mention of its manmade famines that led to some eight million deaths in the USSR in the early 1930s - almost four million in Soviet Ukraine alone-a taboo that remained in place until the late 1980s.

Imperial and colonial governments have justified and understated the horrific results of their policies. Soviet collectivization policies and the famines that accompanied, followed, or were linked to them can be understood as deriving from an imperial view that large parts of humanity are expendable in the building of a modern, industrial, militarily more powerful and greater imperial state and civilization. Soviet collectivization, which can be seen as constituting part of a great transformation of Soviet society of the 1930s, has been depicted as a war against the peasantry, resembling a military occupation conducted by militarized Communist Party members and reinforced and supported by Red Army soldiers and internal security service (OGPU) troops (Tarkhova; Romano and Tarkhova). ${ }^{9}$

The devastating famine that ravaged Soviet Ukraine in 1932-33, subsequently known as the Holodomor, has been studied and compared recently with other contemporary or nearly simultaneous famines that occurred in other parts of the Soviet Union, including in Soviet Kazakhstan, as well as with the 1958-62 famine in China, and with other state-induced famines in communist-ruled countries (see, for instance, Graziosi and Sysyn). ${ }^{10}$ It seems that further study and comparison of the Holodomor (and

\footnotetext{
${ }^{9}$ See also Andrea Graziosi's The Great Soviet Peasant War, who argues that Bolshevik policies toward the peasantry amounted to the "Thirty Years War" of the twentieth century. This long essay, a revised version of a 1996 article, is published in his Stalinism, Collectivization and the Great Famine, pp. 5-64.

10 For discussions on the Holodomor and the other Soviet famines that appeared in the wake of the publication of Anne Applebaum's Red Famine, see especially the comments by the two experts on the Kazakh famine, Niccolò Pianciola and Sarah Cameron. See also Rhoda E. Howard-Hassman's comparison of communist famines.
} 
other Soviet famines, especially the Kazakh) with famines referred to as colonial or that took place in colonial-administered lands is needed. ${ }^{11}$

The Soviet state, established following the collapse of the tsarist-ruled Russian Empire in 1917, succeeded in reassembling most of its territories and nationalities, but its foundational, unifying principles were now based on communist ideology and the promotion of communist ideas, as well as on a contradictory anti-imperial platform that emphasized internationalism and promised to satisfy within one state the strivings of the non-Russian nations and peoples for autonomy and national cultural development. This multi-national state of formally sovereign national republics and lower-level national- or ethnic-based administrative units was structured as a federation, making it unique among empires, and not immediately or easily recognizable as one.

Unlike federal states, however, where subjects of the federation retain certain powers or share powers with the central government, in the Soviet Union, republic-level governments and branches of the Bolshevik party were subject to highly centralized control from the leadership of the Bolshevik Party (later Communist Party of the Soviet Union) based in the Kremlin, in Moscow, located in the Russian heartland. Centralization was facilitated when the Bolshevik party leadership began eliminating all opposition political parties and established a dictatorship soon after taking power. Although allowing for some autonomy in the 1920s, especially in national cultural development in the non-Russian republics, the units subordinate to the centre became subject to increasing centralization from the metropole that made the inequality of the centre-subcentre relationship even greater and more evident. ${ }^{12}$

In Ukraine, where important cultural and political figures were already being repressed or eliminated in the 1920s, repressions became wider in scope and intensity by the 1930s, when national communists were also targeted. ${ }^{13}$ Nationality-based repressions and even ethnic cleansing were

\footnotetext{
11 Niccolò Pianciola writes that "the more sources I read in archives in Kazakhstan and Russia, the more a strong central agency in the mass deaths of Kazakhs becomes apparent," pointing out that while Kazakhs were starving, meat from their livestock was being sent to Moscow, Leningrad, and other industrial centres, and livestock from Kazakh herds was being sent to collective farms outside Kazakhstan ("Ukraine and Kazakhstan" 442-43). See also his "Stalinskaia 'ierarkhiia potrebleniia."'

12 Valerii Vasyl'iev addresses the centre-subcentre political relationship between the central Soviet and Ukrainian leadership in Politychne kerivnytstvo URSR i SRSR.

13 In the 1920s there were still significant numbers of both anti-communist intellectuals in Soviet Ukraine and supporters of national communism within the Ukrainian branch of the Bolshevik party, exemplified by such figures as Oleksandr
} 
being normalized by the middle of the 1930s (Martin 311-343). In the late 1920s and early 1930s, Stalin also succeeded in consolidating control over the Bolshevik party. Even more power was becoming concentrated in its small decision-making body, the politburo, controlled by Stalin. By the middle of the 1930s, Kremlin authorities were strongly promoting Russian imperial history, Russian culture and language use, and more generally, Russo-centric propaganda. Thus, the Soviet state, while still retaining its form as a federation, was becoming more closely associated with the core Russian nationality, elevating and promoting it (see Brandenberger; Barghoorn).

While the Soviet Union was generally viewed as an empire by scholars who treated the Soviet Union as a totalitarian state, in the last years of its existence and then following the collapse of the USSR a new literature on the USSR as empire appeared. Some of the scholars associated with this emerging trend deliberately distinguished themselves from the so-called totalitarian school (Motyl 3). This more recent historiography, in which the building of a new type of imperial, multi-national state was viewed by some of the scholars with a degree of favour-at least the Soviet state of the 1920s-warrants comparison with earlier treatments of the USSR as a totalitarian state. ${ }^{14}$

Soviet Ukraine was the most populous non-Russian republic in the USSR, known for its rich agricultural farmland and as its most important grainproducing region. Yet Ukraine suffered through several famines during the

Shums'kyi and Mykola Skrypnyk, who were critical of centralized control from Moscow. In 1928, the economist Mykhailo Volobuiev wrote that Ukraine had been a colony in imperial Russia and denounced the Kremlin's economic policies in the Soviet era as continuing the colonial policies of the past. Mass arrests and a show trial of anti-communist intellectuals took place in 1929-30, while the national communists were purged and eliminated starting in 1932. On national communism in Ukraine, see Mace.

${ }^{14}$ For examples of the newer historiography, see Kivelson and Suny (especially the introductory chapter, "Thinking about Empire," which discusses the term "empire" and Russia's imperial forms); and Martin. Martin even coined the term "affirmative action empire" to denote an empire that promoted in the 1920s the national cultural development of its minorities. Hirsch, however, in her study, cautions against idealizing Soviet affirmative action policies of the 1920s, and sees not a retreat from but rather continuity in Soviet policies from the 1920s to the 1930s (see 9, incl. fn. 21). Of the more recent literature, Andreas Kappeler stresses imperial continuity, viewing the breakup of the Soviet Union as falling within the process of the breakup of European empires. For some examples of earlier literature see, for instance, Conquest's The Last Empire: Nationality and the Soviet Future, and his earlier The Last Empire. See also Kolarz's Communism and Colonialism, and his earlier Russia and Her Colonies; and Pipes. 
period it was part of the Soviet Union, three of them catastrophic: in 1921$23,1928-29,1932-33$, and $1946-47.15$ It was also subject to famine-inducing policies under Nazi Germany's occupation. De Waal, commenting on Ukraine as an epicentre of major European famines in the twentieth century, noted that because of its soil fertility, Ukraine's grain served as "the foundation of land empires. That was its curse: the wheat fields were coveted by rulers from both east and west" (75).

However, famines that occurred in Ukraine under Soviet rule, in particular the devastating famine of 1932-33, have not been analyzed closely in the context of imperialism and colonial rule. ${ }^{16}$ Such an approach is warranted. With the adoption of the first Five-Year Plan, central authorities in Moscow assumed greater control over Ukraine's economy during which the republic was treated as an economic colony to subsidize development in

15 The famine of 1921-23 affected both Russian (the Volga region) and Ukrainian territories (the south). Grain from Ukraine was exported to Russia primarily to feed the hungry in Russia's Volga region, even though Ukraine was also suffering from famine (see Serbyn). Serbyn concluded that although Ukraine was formally a sovereign state, its Bolshevik government "behaved like agents of Moscow's colonial rule and exploitation of Ukraine" (183). The largely unknown 1928-29 famine is the topic of a recent study by Hrynevych who stresses that Soviet authorities were conducting grain requisitions in Ukraine during a period of severe food shortages and famine. The famine of 1932-1933 in Ukraine-known as the Holodomor-is the topic of many studies. For a recent treatment by an award-winning journalist, see Applebaum. For a summary work in English by a leading Ukrainian expert on the Holodomor, see Kulchytsky, The Famine of 1932-1933. For a treatment of the panSoviet famines of 1931-33, including the famine in Ukraine, see Davies and Wheatcroft. The 1946-47 famine has not been as thoroughly studied as the Soviet famines of 1931-33. Ganson concludes that the Soviet leadership could have prevented a mass famine but for political reasons did not do $(114-15,146)$. See also Ellman who posits that the excess deaths of an estimated one to 1.5 million people could have been prevented. Wheatcroft is less critical of the regime, arguing that the famine of 1946-47 conformed to other Soviet famines that followed droughts and sharp drops in grain production after years of food shortages (987 and 1004-05). The late Oleksandra Veselova was Ukraine's leading expert on this famine. She argued that the Soviet state was responsible for the famine through obligatory grain deliveries, depriving people of the means for survival (see "Famine in Ukraine" esp. 196, and "Henotsyd Holodomorom 1946-1947 rokiv v Ukraini"). Veselova points to the dependent, colonial status of Ukraine's government and its officials who obediently followed the centre's directives on grain collections during drought conditions and falling agricultural output. In Russian, the major study is by Zima, who faults the regime for its inhumane policy of holding grain in reserve during the famine.

16 The diaspora historian Dmytro Solovei wrote a short study examining the 192122 and 1932-33 famines. Despite its title's suggestion, this long essay does not examine the question of Ukraine as a colony or the nature of colonial rule in Ukraine. 
other parts of the Soviet Union. About one third of the capital formed in Ukraine during the period was exported, which constituted an unsustainably high $15 \%$ of national income. Much of this revenue came from Ukraine's agricultural sector (Krawchenko 116-17; Melnyk, Soviet Capital Formation 107-08; and his more recent "Ukraine Within the USSR" 122-24). Ukraine was also subjected to direct rule by the Kremlin beginning in late 1932-early 1933, which was the period when famine conditions were most intense. This occurred at the same time that the Kremlin was reinforcing its grain collection efforts to force the republic's producers to meet the country's assigned quota. Ukraine can thus be seen as being treated somewhat similarly to an overseas colony when colonial officials failed to carry out central directives effectively in ensuring the profitable exploitation of the colonies, or were regarded as untrustworthy, and even of being disloyal. ${ }^{17}$ In addition to making key changes in the republic's top leadership, central authorities organized thoroughgoing purges of lower-ranking officials that led to the replacement of 70 percent of district-level Communist Party secretaries and more than half of all collective farm chairmen (Vasyl'iev 28687).

Grain procurement quotas and agricultural polices imposed on Ukraine thus deserve careful study in the context of colonial-type exploitation (examined by Liudmyla Hrynevych in her essay in this special issue focusing on the late 1920s), and in comparison with other regions of the USSR. The percentage of grain procured from Ukraine compared to all the other regions of the USSR, for instance, was raised from 29 percent in 1926-27 to 38.3 percent in 1927-28 (Slyn'ko 75). It should be noted that the percentage of grain procured by the centre from Ukraine's harvests was also very high, especially in 1931 , when at least 41.3 percent of the harvest was taken. This was considerably higher than the average of 32 percent for all major regions of the USSR. ${ }^{18}$ Russian historian N. A. Ivnitskii calculated that Ukraine's 1931

\footnotetext{
17 Vasyl'iev discusses in detail the institution of direct rule, the figures installed or sent to Ukraine to carry out the Kremlin's directives, and the subordination to the Kremlin of Ukraine's leadership in the context of the relations between Ukrainian leaders and Kremlin authorities during the unfolding famine crisis (252-91; 283-84). 18 Other major grain-producing regions of the USSR had large percentages of their harvests procured, but nor as large as Ukraine's. These include the northern Caucasus (34.2\%), Lower Volga (41\%), Central Volga (38.6\%), and Kazakh ASSR (39.5\%) (Kondrashin 144-45). Ukrainian scholars have pointed to Ukraine's heavy grain quotas in comparison with other regions of the USSR. See, for instance, Kulchytsky's discussion of the 1930 and 1931 grain quotas, and the politics and consequences, especially peasant disturbances, linked to these (The Famine of 1932 1933 41-48, esp. 47-48). See also the chart showing the amount of grain taken from Ukraine and other grain-producing regions of the USSR from the 1930 and 1931
} 
grain collection quota, including the milling fee, constituted 50 percent of the biological harvest estimate. He concluded that this created a "catastrophic situation for Ukraine" (Ivnitskii 128-29). Another Russian historian, Sergei Nefedov, estimated that 58 percent of the grain harvested at collective farms in Ukraine was taken to meet the 1931 quota (Ellman and Nefedov 1059).

In her essay, Liudmyla Hrynevych proposes that application of theoretical models of dependency and imperialism can explain important aspects of Communist Party leader Joseph Stalin's faminogenic ${ }^{19}$ policies in the Soviet Union. While Stalin's "revolution from above" in the late 1920searly 1930s resulted in food shortages throughout and deadly famines in various regions of the USSR, Hrynevych maintains that the imposition of this "communist experiment" was intensified in Ukraine and other territories of the USSR by the top-down relations of the centre (the Kremlin, in Moscow) to the peripheral regions like Ukraine (with its capital then in Kharkiv). This top-down relationship featured the use of political domination and control over economic resources in ways that were injurious to the peripheral regions, especially Ukraine. These factors, Hrynevych suggests, led to mass deaths through famine.

In buttressing her thesis, Hrynevych points to decisions of the Kremlin leadership in the late 1920s, in conjunction with the adoption of the first Five-Year Plan. These choices intensified Ukraine's specialization as a granary of the USSR, placing unrealistic expectations on future grain production goals. Ukraine was saddled with the task of supplying graindeficit regions and cities of the USSR as well as produce for export. Hrynevych stresses the importance of the decision in 1928 to dissolve the Ukraine-based trust Ukrkhlib (Ukrainian Bread) and its takeover by Soiuzkhleb (Union Bread) based in Moscow, a move that gave the centre full control over grain collections, exports, and distribution. The economic planning decisions made in the metropole led to the charge in 1928 by the young Ukrainian economist Mykhailo Volobuiev that the centre was continuing the exploitative colonial practices of the past when Ukraine had been a colony of the Russian Empire.

harvests, and the grain quotas established for 1932 (Kul'chyts'kyi, Stalins'kyi "sokrushitel'nyi" udar 1932-1933 209-10). Kulchytsky emphasizes that the amount of grain taken from Ukraine's 1930 harvest exceeded the total taken from all of the USSR's other major grain-producing regions combined. This had never occurred earlier - neither before the revolution nor during the NEP years.

19 David Marcus coined the term "faminogenic" to describe state policies and activities that create famine conditions or that support their creation, and proposed establishing four levels of criminal responsibility for states that cause famines or fail to respond promptly and effectively in alleviating food shortages and famine conditions (245n9). 
Hrynevych then examines grain collection and distribution policies and actions taken by or authorized by Kremlin authorities and their administrators in Ukraine on the eve of and during the little-known 1928-29 famine in Ukraine. With drought conditions pointing toward a failing harvest, the Kremlin sent its envoy Anastas Mikoian to Ukraine, who insisted that the republic rely on its own resources to feed its population. Hrynevych argues that the aid authorized by the Kremlin after famine struck should be seen as a typically imperial practice given that the exploitation of the republic continued as the Kremlin cut Ukraine's budget during the crisis. The centre also insisted that Ukraine continue making payments to the state grain fund until early 1929 , and grain continued to be procured from the republic despite the harvest failure. Hrynevych suggests that the food aid given Ukraine in 1933 during the peak of the 1932-33 famine should be seen in the same way, as the assistance represented only a partial return of grain that had been requisitioned earlier.

The Ukrainian famine of 1932-33 (Holodomor) has been compared to the Irish Great Famine (Gorta Mór) of the 1840s (see Noack et al., Holodomor and Gorta Mór; Curran et al.). ${ }^{20} \mathrm{~A}$ comparison of the histories of the Irish and Ukrainian peoples shows parallels in the modern period. Both were subordinate political units of imperial states that suffered through horrific famines prior to achieving independence. Although Ireland and Ukraine were integrated into imperial political structures, with Ukraine having, formally, attributes of statehood as a republic, the two units were dependent on decisions made in the metropole. Moreover, mass starvation and the deaths of millions occurred in regions where the overwhelming majority of the population was ethnically different from those living in or near the imperial centre.

In both countries the famines have been enshrined in their national narratives and feature in national identity formation and the politics of collective memory. ${ }^{21}$ The editors of a collection of essays on the Irish and Ukrainians famines stressed "the centrality of [the] two famines for the development of modern Ireland and modern Ukraine" while noting that historians of empire have tended not to pay much attention to the historical parallels (Noack et al., "Introduction" 1).

Michael Hechter in his essay does compare the two famines in the context of internal colonialism and alien rule. In the 1970s, he authored a seminal study on the extension of control over the Celtic fringe, which was culturally distinct from the core territories of Great Britain, and discussed how this influenced regional economic development of the Celtic lands

\footnotetext{
20 The volume edited by Curran et al. also examines the Finnish famine of the 1860s.

${ }^{21}$ For an example of similar cultural engagement with famine memory in Ireland and Ukraine, see Holt and Mahoney.
} 
(Hechter, Internal Colonialism). Applying views developed in this book and in his latest study (Alien Rule), Hechter notes in his article that both Ukraine and Ireland were dependent peripheral regions in imperial states that were subjected to alien rule. While integrated politically into metropolitan state structures, the experiences of Ukraine and Ireland also mirrored in part those of European overseas colonies. For many Western European countries, Hechter observes, state building entailed internal colonialism, where the lack of political sovereignty of internal colonies placed limits on their economic welfare and threatened their cultural integrity.

In comparing the Irish and Ukrainian famines, Hechter notes the policy in both the UK and the USSR of continued export of agricultural goods. As native leaders would be more likely to respond to grievances from subjects close to home, Hechter posits that had Ireland and Ukraine been selfgoverning, their political leaders may have taken decisive steps to relieve the suffering. Rather than viewing the two famines as outcomes exclusively tied to ideology, Hechter proposes they also be seen as by-products of alien rule, as foreign rulers are less likely to be concerned about the well-being of different peoples in peripheral regions; moreover, the relationship between the core and peripheries tends to be rather exploitative. According to Hechter, the main goal of establishing control over alien territory through conquest-which requires the expenditure of both human and material resources on the part of the conquering power-is to gain profit for the core regime.

The difficulties in determining whether the Irish Great Famine can be seen as colonial are discussed in the essay by Peter Gray. While acknowledging that Ireland had a long-standing colonial relationship with England and later Great Britain, Gray points to ambiguities in this relationship caused by the creation of a "hybrid entity," following the Act of Union of 1800. This act, while integrating Ireland into imperial state structures also retained structural legacies from the period of direct colonial subordination.

Gray also surveys historical literature of various schools that examined socio-economic structures existing in 1845; the trigger mechanisms for the famine; and factors that determined the state's response to the famine. He concludes that identifying a clearly colonial dimension is difficult beyond the structural factor of the acute levels of potato dependency. Government policy, he notes, did not differ toward Scotland at the time where there also was a potato famine. However, the situation in Ireland differed from that in Scotland because of the continuing colonial legacy, in which the basic social structures inherited from the earlier period of direct colonial rule remained. Gray concludes that the continued use of military force by the British as state policy against Irish nationalists and as a means to quell outbreaks of social violence should be seen as a colonial-type practice. 
The Soviet famines of 1931-33 occurred in a communist state with sizeable national minorities. In his essay on the famine of 1958-1962 in China, Lucien Bianco makes comparisons to the famines in the Soviet Union of the early $1930 \mathrm{~s} .{ }^{22} \mathrm{He}$ stresses that although the Chinese famine is notable as the most murderous in human history in absolute numbers, proportionately fewer died in China than during the famines in Soviet-ruled Kazakhstan and Ukraine. For the entire Soviet Union, however, the proportion of famine deaths was somewhat less than in China. Similarities include rapid urbanization due to policies of accelerated industrialization, which in both countries was financed largely at the cost of the rural economies and peasantry. One of the direct causes of famine in both countries were ruthless and excessive grain requisitions that continued even while famine raged.

Bianco points out that in contrast to the Soviet Union where national minorities constituted the majority of victims, death rates were lower among minorities in China. Minority regions in the northern and western peripheries of China were not important grain-producing regions and were not well integrated or connected to transportation infrastructure, so their mandatory deliveries of grain to the state were much lower or non-existent. In provinces where both Han Chinese and Tibetans lived, both ethnic groups suffered alike during the famine. In China, Han peasants constituted the overwhelming majority of famine victims, while peripheral provinces containing ethnic minorities suffered less. Comparing the Soviet and Chinese famines, Bianco notes that while about five percent of Chinese famine deaths constituted ethnic minorities, this figure was about 80 percent in the Soviet Union.

The study of genocide and the destruction of ethnic, religious, and social communities, and nations owes much to Raphaël Lemkin. In his pioneering study Axis Rule in Occupied Europe, Lemkin viewed the mass killings under Nazi Germany in World War II as linked to a colonial project. It was in this study that Lemkin coined the term "genocide" and elaborated on its meaning. In his article for this special issue, Douglas Irvin-Erickson emphasizes that Lemkin did not limit his understanding of genocide to instances of mass killing but more broadly to include the destruction of heterogeneous communities for the purpose of creating homogeneous ones. Irvin-Erickson notes that as a young jurist Lemkin paid close attention to the development of Soviet law. In supporting the creation of a communist society, Soviet law authorized and legitimized the arrest, suppression, oppression, and killing of people who had a social consciousness deemed to

\footnotetext{
22 Bianco discusses in more detail similarities and differences between the Soviet and Chinese famines in a previously published article. See also Graziosi "Stalin's and Mao's Famines."
} 
be criminal. State violence and coercion was sanctioned to destroy and transform bourgeois groups and national minorities into Soviet citizens. Genocide under Soviet auspices was thus legitimized through laws, some of which called for the removal of national minorities from society under slogans of social protection. The goal was to create, destroy, and reorganize social relationships by managing identity formation in support of the Soviet revolutionary project and state.

Applying his understanding of genocide to the mass killings and repressions in Ukraine, Lemkin saw the famine of 1932-33 as the most brutal act within a wider pattern of the destruction of a nation. In notes prepared for a planned study of the history of genocide, Lemkin outlined his views on the Ukrainian genocide, considering the famine as a component of a fourpronged attack against the Ukrainian people. The others parts were severe repressions against the intelligentsia, destruction of the national church, and a long-term policy aimed at the dispersion and emigration of Ukrainians from Ukraine, and the immigration of Russians into the republic, the ultimate goal being a weakening of the cohesiveness of the Ukrainian nation. According to Irvin-Erickson, Lemkin viewed famine and hunger as tools for committing genocide-as violence targeting large numbers of individuals that placed them in competition with one another in a struggle for survival, turning famine victims into enemies of one another. Lemkin noted that famine and hunger thus destroyed social bonds of trust and solidarity, inflicting permanent damage to an individual's sense of belonging and trust in a society. In line with Lemkin's views, as pointed by Irvin-Erickson, the Ukrainian peasantry was sacrificed to promote uniformity. As the patterns of economic organization of most of those identifying as Ukrainian were antithetical to the plans of the Soviet state, they were targets. The goal of the Soviet state was to create Soviet national unity by the complete destruction of all cultures and all ideas save one-Soviet.

In chapters 8 and 9 of Axis Rule in Occupied Europe, Lemkin wrote about regulations and anti-Jewish laws that introduced restrictions, including food rationing based on racial criteria. These racially-motivated preferences privileged German nationals, who were to be provided with 100 percent of their caloric needs, while other ethnic and national groups were to receive less: Greeks were to receive 30 percent, while Jews, who were at the bottom of the food rationing hierarchy, 20 percent. Irvin-Erickson asserts that Lemkin saw this discrimination in access to food as an element in a larger pattern of endangering undesired national groups. Laws were passed prohibiting Jews from leaving ghettos for food, with infractions punishable by execution. Jewish Councils, or Judenrat, were to function as tools to shatter the bonds of social cohesion, as Jewish victims were forced into competition with one another for survival. Irvin-Erickson's article highlights Lemkin's conclusion that ghetto life showed that techniques of genocide 
could be economic and political levers that deprive people of basics like food and shelter. As friends, neighbours, and family members were forced to compete for food, thinking in more general and national terms became impossible. Irvin-Erickson concludes that to Lemkin, this constituted the destruction of group life and the shattering of social bonds, as enforced starvation proved to be effective in destroying the national pattern of a targeted group.

The essays in this special issue collectively demonstrate that famines which have occurred in colonies and former colonies, or in peripheral regions (internal colonies) of empires, especially where the economies are largely rural-based, can be fruitfully studied within the context of imperial policies and colonial rule. Starvation as state policy was practised in Ukraine, Moldova, and Poland under Nazi German and Romanian occupation during World War II, which was directly linked to their expansionist and empirebuilding efforts. The catastrophic famines in British-ruled Ireland and India took place in an overseas colony (India) or former colony (Ireland). India, however, was a distant colony containing racially different peoples, while Ireland was closer to the imperial centre and inhabited largely by Celts, who were of the same race and culturally closer to the English. In the cases of Ireland and Ukraine, neither were ruled like an overseas colony during their famines. Rather, both were treated more like internal colonies (peripheral regions of empires) that were in the process of being integrated into imperial political structures, which were controlled largely by representatives of the core nationalities. Ukrainians, thus, found themselves in a somewhat similar cultural relationship to the Russians as the Irish to the English. Both Ukraine and Ireland suffered catastrophic famines as peripheral regions (internal colonies) - inhabited largely by minority nationalities — of imperial states. In the case of the Chinese famine, however, no link seems to exist between the policies of the imperial centre and famine in peripheral regions where ethnic minorities were concentrated. The Chinese famine, instead, was most intense in the grain-producing regions inhabited largely by Han Chinese, who constituted the core nationality of the Chinese state.

Recent scholarly literature has established the political nature of modern famines, if not always in their causes then certainly in the reactions and responses of state authorities to food shortages and the onset of famine conditions. The cases of Ukraine and Ireland, as well as Bengal, demonstrate some similarities in that the responses of the imperial authorities were woefully inadequate to mitigate the worst of the suffering and deaths from starvation. In the case of Ukraine, however, the authorities caused the famine through their policies. Moreover, they intensified famine conditions, causing additional suffering and deaths, by authorizing searches and the confiscation of food found in the homes of the peasantry, even from already-starving peasant households. Overall, the famines that occurred in overseas colonies 
or peripheral regions (internal colonies) of empires suggest that the investigation of links between imperial policies, colonial rule, and famine merit further study, especially in the case of the Soviet Union and its internal colonies. 


\section{Works Cited}

Applebaum, Anne. Red Famine: Stalin's War on Ukraine. Doubleday, 2017.

Barghoorn, Frederick C. Soviet Russian Nationalism. Oxford UP, 1956.

Berkhoff, Karel C. "Famine in Kiev." Harvest of Despair: Life and Death in Ukraine under Nazi Rule, The Belknap Press, 2004, pp. 164-86.

Bianco, Lucien. "Comparing the Soviet and Chinese Famines: Their Perpetrators, Actors and Victims." Communism and Hunger: The Ukrainian, Kazakh and Soviet Famines in Comparative Perspective, edited by Andrea Graziosi and Frank E. Sysyn, Canadian Institute of Ukrainian Studies P, 2016, pp. 59-82.

Brandenberger, David. National Bolshevism: Stalinist Mass Culture and the Formation of Modern Russian National Identity, 1931-1956. Harvard UP, 2002.

Brandon, Ray, and Wendy Lower, editors. The Shoah in Ukraine: History, Testimony, Memorialization. Indiana UP, 2008.

Cameron, Sarah. "Questioning the Distinctiveness of the Ukrainian Famine." Contemporary European History, vol. 27, no. 3, 2018, pp. 460-64. DOI: $10.1017 /$ S0960777318000346

Collingham, Lizzie. The Taste of War: World War II and the Battle for Food. The Penguin Press, 2012.

Conquest, Robert, editor. The Last Empire. Ampersand Books, 1962.

---. The Last Empire: Nationality and the Soviet Future. Hoover Institution Press, 1986.

Curran, Declan, et al., editors. Famines in European Economic History: The Last Great European Famines Reconsidered. Routledge, 2015.

Davies, R. W., and Stephen G. Wheatcroft. The Years of Hunger: Soviet Agriculture, 1931-1933. Palgrave Macmillan, 2004.

Davis, Mike. Late Victorian Holocausts: El Niño Famines and the Making of the Third World. Verso, 2001.

Devereux, Stephen. Famine in the Twentieth Century. IDS Working Papers, vol. 105, 2000, $\quad$ https://www.ids.ac.uk/download.php?file=files/dmfile/wp105.pdf. Accessed 8 Mar. 2021.

---. "Introduction: From 'Old Famines' to 'New Famines.'” The New Famines: Why Famines Persist in an Era of Globalization, edited by Stephen Devereux, Routledge, 2007, pp. 1-26.

De Waal, Alex. Mass Starvation: The History and Future of Famine. Polity Press, 2018.

Edkins, Jenny. "The Criminalization of Mass Starvations: From Natural Disaster to Crime against Humanity." The New Famines: Why Famines Persist in an Era of Globalization, edited by Stephen Devereux, Routledge, 2007, pp. 50-65.

Ellman, Michael. "The 1947 Soviet Famine and the Entitlement Approach to Famines." Cambridge Journal of Economics, vol. 24, no. 5, 2000, pp. 603-30. DOI: 10.1093/CJE/24.5.603

Ellman, Michael, and Sergei Nefedov. "The Soviet Famine of 1931-1934: Genocide, a Result of Poor Harvests, or the Outcome of a Conflict between the State and the Peasants?" Europe-Asia Studies, vol. 71, no. 6, 2019, pp. 1048-65. DOI: 10.1080/09668136.2019.1617464

Ganson, Nicholas. The Soviet Famine of 1946-47 in Global and Historical Perspective. Palgrave Macmillan, 2009. 
Graziosi, Andrea. The Great Soviet Peasant War: Bolsheviks and Peasants, 1917-1933. Ukrainian Research Institute of Harvard University, 1997.

---. "Stalin's and Mao's Famines: Similarities and Differences." Communism and Hunger: The Ukrainian, Kazakh and Soviet Famines in Comparative Perspective, edited by Andrea Graziosi and Frank E. Sysyn, Canadian Institute of Ukrainian Studies P, 2016, pp. 83-101.

---. Stalinism, Collectivization and the Great Famine. Ukrainian Studies Fund, 2009.

Graziosi, Andrea, and Frank E. Sysyn, editors. Communism and Hunger: The Ukrainian, Kazakh and Soviet Famines in Comparative Perspective. Canadian Institute of Ukrainian Studies P, 2016.

Hechter, Michael. Alien Rule. Cambridge UP, 2013.

---. Internal Colonialism: The Celtic Fringe in British National Development. U of California P, 1975.

Hirsch, Francine. Empire of Nations: Ethnographic Knowledge and the Making of the Soviet Union. Cornell UP, 2005.

Holt, Emily, and Grace Mahoney. "Rupture and Call: Famine Encounters from Contemporary Irish and Ukrainian Women in the Arts." East/West: Journal of Ukrainian Studies, vol. 7, no. 2, 2020, pp. 69-97. DOI: 10.21226/ewjus612

Howard-Hassmann, Rhoda E. State Food Crimes. Cambridge UP, 2016.

Hrynevych, Liudmyla. Holod 1928-1929 rr. u radians'kii Ukraini. Instytut istorii Ukrainy, 2013.

Ivnitskii, N. A. Golod 1932-1933 godov v SSSR: Ukraina, Kazakhstan, severnyi Kavkaz, Povolzh'e, zapadnaia Sibir', Ural. Sobranie, 2009.

Kappeler, Andreas. The Russian Empire: A Multiethnic History. Longman, 2001.

Kivelson, Valerie A., and Ronald Grigor Suny. Russia's Empires. Oxford UP, 2017.

Kolarz, Walter. Communism and Colonialism. St. Martin's Press, 1964.

---. Russia and Her Colonies. 3rd edition, G. Philip, 1953.

Kondrashin, Viktor. Golod 1932-1933 godov: tragediia rosiiskoi derevni. ROSSPEN, 2018.

Krawchenko, Bohdan. Social Change and National Consciousness in Twentieth-Century Ukraine. Canadian Institute of Ukrainian Studies P / St. Antony's College, 1987.

Kulchytsky, Stanislav. The Famine of 1932-1933 in Ukraine: An Anatomy of the Holodomor. Canadian Institute of Ukrainian Studies P, 2018.

--- (Stanislav Kul'chyts'kyi). Stalins'kyi "sokrushitel'nyi" udar 1932-1933. Kyiv, Tempora, 2013.

Lemkin, Raphael (Raphaël Lemkin). Axis Rule in Occupied Europe: Laws of Occupation, Analysis of Government, Proposals for Redress. Carnegie Endowment for International Peace, 1944.

Lower, Wendy. Nazi Empire-Building and the Holocaust in Ukraine. U of North Carolina P, 2005.

Mace, James E. Communism and the Dilemmas of National Liberation: National Communism in Soviet Ukraine 1918-1933. Harvard Ukrainian Research Institute, 1983.

Marcus, David. "Famine Crimes in International Law." The American Journal of International Law, vol. 97, no. 2, April 2003, pp. 245-81. DOI: 10.2307/3100102

Martin, Terry. The Affirmative Action Empire: Nations and Nationalism in the Soviet Union, 1923-1939. Cornell UP, 2001. 
Mazower, Mark. Hitler's Empire: How the Nazis Ruled Europe. Penguin Books, 2008.

Melnyk, Z. Lew (Zinowij Lew Melnyk). "Ukraine within the USSR: An Economic Perspective, 1928/29-1932 and 1959-1980." Nationalities Papers, vol. 35, no. 1, 2007, pp. 121-69. DOI: 10.1080/00905990601129438

---. Soviet Capital Formation. Ukraine, 1928/29-1932. Ukrainian Free UP, 1965.

Motyl, Alexander J. Imperial Ends: The Decay, Collapse, and Revival of Empires. Columbia UP, 2001.

Noack, Christian, et al., editors. Holodomor and Gorta Mór: Histories, Memories, and Representations of Famine in Ukraine and Ireland. Anthem Press, 2012.

---. "Introduction. Holodomor and Gorta Mór: Histories, Memories and Representations of Famine in Ukraine and Ireland." Holodomor and Gorta Mór: Histories, Memories and Representations of Famine in Ukraine and Ireland, edited by Christian Noack et al., Anthem Press, 2012.

Ó Gráda, Cormac. Famine: A Short History. Princeton UP, 2009.

Pianciola, Niccolò. “Stalinskaia 'ierarkhiia potrebleniia' i velikii golod 1931-1933 gg. v Kazakhstane." Ab Imperio, vol. 2, 2018, pp. 80-116.

---. "Ukraine and Kazakhstan: Comparing the Famines." Contemporary European History, vol. 27, no. 3, 2018, pp. 440-44.

Pipes, Richard. The Formation of the Soviet Union, Communism and Nationalism, 19171923. Harvard UP, 1954.

Polanyi, Karl. The Great Transformation: The Political and Economic Origins of Our Time. Beacon Press, 2001 (C1944).

Romano, Andrea, and Nonna Tarkhova. L'Armata Rossa e la collettivizzazione delle campagne nell'URSS, 1928-1933: raccolta di documenti dai Fondi dell'Archivio militare di Stato Russo. Instituto universitario orientale, 1996.

Sen, Amartya. Development As Freedom. Alfred A. Knopf, 2001.

---. Poverty and Famines: An Essay on Entitlement and Deprivation. Clarendon Press, 1981.

Serbyn, Roman. "The Origin of the Ukrainian Famine of 1921-23 in the Light of Recent Research." Famine-Genocide in Ukraine, 1932-1933: Western Archives, Testimonies and New Research, edited by Wsevolod W. Isajiw, Ukrainian Canadian Research and Documentation Centre, 2003, pp. 165-83.

Slyn'ko, I. I. Sotsialistychna perebudova i tekhnichna rekonstruktsiia sil's'koho hospodarstva Ukrainy (1927-1932 rr.). Vyd. Akademii nauk Ukr. SSR, 1961.

Snyder, Timothy. Black Earth: The Holocaust as History and Warning. Tim Duggan Books, 2015.

---. Bloodlands: Europe between Hitler and Stalin. Basic Books, 2010.

---. "Germany's Historical Responsibility for Ukraine." Marieluise Beck. Mitglied des Deutschen Bundestags. 20 June 2017, https://marieluisebeck.de/artikel/20-062017/timothy-snyder-germanys-historical-responsibility-ukraine. Accessed 20 Feb. 2020.23

23 The text of the talk, titled "Germans must remember the truth about Ukraine-for their own sake," can also be read here: https://www.eurozine.com/germans-mustremember-the-truth-about-ukraine-for-their-own-sake/. Accessed 22 Feb. 2021. 
Solovei, Dmytro. Holod u systemi koloniial'noho panuvannia TsK KPSS v Ukraini (do 40-litn'oho iuvileiiu KP(b)U i 25-oi richnytsi holodu 1932-1933 rr. v Ukraini. Institute for the Study of the USSR, 1959.

Tarkhova, Nonna. Krasnaia Armiia i stalinskaia kollektivizatsiia, 1928-1933 gg. ROSSPEN, 2010.

Vasyl'iev, Valerii. Politychne kerivnytstvo URSR i SRSR: dynamika vidnosyn tsentrsubtsentr vlady (1917-1938). Instytut istorii Ukrainy, 2014.

Veselova, Oleksandra. "Famine in Ukraine after the Second World War." Harvard Ukrainian Studies, vol. 30, nos. 1-4, 2008, pp. 183-98.

---. "Henotsyd Holodomorom 1946-1947 rokiv v Ukraini." Problemy istorii Ukrainy: Fakty, sudzhennia, poshuky. Mizhvidomchyi zbirnyk naukovykh prats', vol. 7, 2003, pp. 384-405.

Wheatcroft, Stephen. "The Soviet Famine of 1946-1947, the Weather and Human Agency in Historical Perspective." Europe-Asia Studies, vol. 64, no. 6, 1XZ, Aug. 2012, pp. 987-1005. DOI: 10.1080/09668136.2012.691725

Zima, F. V. Golod v SSSR 1946-1947: proiskhozhdenie i posledstviia. Rossiiskaia akademiia nauk / Institut rossiiskoi istorii, 1996. 